\title{
BRAIN DEATH — A CURRENT PROBLEM OF OUR TIME
}

\author{
Monika Saran ${ }^{1}$, Brygida Krucinska1, Lukasz Czyzewski \\ 'Student Scientific Circle "NEFRON", Warsaw Medical University, Warsaw, Poland \\ ${ }^{2}$ Department of Nephrology Nursing, Warsaw Medical University, Warsaw, Poland
}

\begin{abstract}
The concept of brain death is a complex philosophical and medical construct which, despite the passage of time and strictly defined deadlines, is incomprehensible and unacceptable for a section of society. The diagnosis of brain death allows one not only to end the pursuit of persistent therapy, but also to collect organs for transplantation and thus help people who have been condemned to death so far. The purpose of this article is to show the public's fears about stating the death of the brain, to realize that the death of the brain is equal to the death of an individual and a reminder of the criteria and rules for the recognition of death by doctors.
\end{abstract}

KEY WORDS: brain death, dying, death criteria

Disaster Emerg Med J 2018; 3(1): 12-14

\section{INTRODUCTION}

Human death has always been a mystery and an extremely dramatic event. Meanwhile, in the light of the laws of biology, dying is rather a continuous process, stretched out over the time. Since the $19^{\text {th }}$ century, the most important part of the human body was a heart which decides about humanity and character of the person. With the development of the sciences, the role of the heart and brain in the living organism was verified. The development of medical techniques has created the need to seek new criteria of death [1].

\section{CRITERIA OF BRAIN DEATH}

Several events have paved the way for the acceptance of brain death: a change in the perception of the phenomenon of death, sealed by the acceptance of the doctrine of the dissociated nature of death (Sydney Declaration, 1968 [2]), the development of medical technology and the emergence and development of transplantology. The concept of brain death was formed in response to the inadequacy of cardiovascular criteria for patients with critical brain damage [3]. Despite the passage of time, the statements of scientists, ethicists and moral authorities, the issue of brain death as a criterion of death is still under discussion [4]. In society, however, it is still neither fully understood nor acceptable.

The main cause of brain damage is the dislodging process, localized in the supratentorial region, associated with trauma or spontaneous bleeding into the cranial cavity. Studies in Poland that have been conducted over the last 15 years by the "Poltransplant" Coordination Centre state, that the primary brain injury corresponds to around $90 \%$ cases of the brain death, while secondary to around 8-10\% [3].

The current and contemporary definition of death in Poland is described in the annex to the Minister of Health's announcement of July 17, 2007, where death is defined as "a process involving tissues and systems at various times, leading to permanent disintegration of the system as a whole" [5].

The commission declaring brain death consists of three doctors: an anaesthesiology specialist, a neurology specialist or a neurosurgeon, and any special- 
ist doctor. The basic condition for determining the death of the brain is to determine the aetiology of brain damage, the exclusion of potential reversible causes of brain damage and a clinical study, namely: a cranial nerve function examination and the apnoea test. Determination of brain death is a multi-stage procedure consisting of a confirmation and exclusion stage, two series of clinical trials in which it is necessary to demonstrate the absence of seven stem reflexes and the occurrence of persistent apnoea. If the instrumental studies are recommended or required they are also performer. Recognition of irreversible brain damage requires the use of a sufficiently long preliminary observation in the case of primary damage, meaning 6 hours, and a secondary one of 12 hours. The procedure for determining the death of the brain is described in detail in the above-mentioned annex to the Minister of Health's announcement of July 17, 2007 [5].

The brain death ruling still provokes controversy both among health care professionals and patients' families due to the spontaneous motor activity that occurs after the death of the brain. This is associated with persistent autonomic reflexes associated with smooth muscle function, persistent spinal cord activity and peripheral cranial nerve activity. The incidence of the above-described reflexes ranges from $14 \%$ to $87 \%$. On the other hand, the occurrence of spontaneous movements imitating conscious motor activity has been very rarely described [6].

\section{DISCUSSION IN MEDICAL SOCIETY}

In 2015, research was conducted on a group of 240 nurses and midwives using the diagnostic survey method, using the authors' questionnaire. The results showed that $50.4 \%$ of respondents recognized that death occurs only when the brain stops working and the heartbeat stops. In turn, $43.3 \%$ of respondents believed that death can be found after the end of brain function despite a beating heart, while $6.3 \%$ had no opinion. The results described above show that educating about brain death should begin in environments that are directly related to health protection [7].

At the beginning of this year a conference on transplantology was held, during which Professor Jan Talar criticized the principles of death rulings applicable in modern medicine and stressed that neither so-called cerebral death nor cardiac arrest have to confirm death.
The professor questioned the definitions of brain death that have been in force for years. In his opinion, in Poland and in Europe, doctors very often give up treatment too early [8]. The expression of such opinions may lead to information noise that affects the public's confusion about brain death and the procurement of organs for transplantation.

The presentation of such positions by people with medical education significantly impedes the work of doctors, nurses, rescuers having contact with the family of a patient with a confirmed brain death, to whom it needs to be explained that the death of the brain is synonymous with the death of an individual. In addition, the expression of such opinions limits the development of an extremely important field of medicine, namely transplantology.

When writing about the death of the brain, one should also mention persistent therapy which is the result of the dynamic development of medicine. Extending life at all costs threatens the patient's dignity as a person and affects the dehumanization of life, the process of dying and medicine itself. Modern medicine has great options for life-long treatment. Rapid technological development and significant progress in the medical sciences have made intensive care an interdisciplinary, dynamically developing field of medicine. Contemporary man tries to set the limits of life and death. In intensive care units (ICUs) there is often a struggle for every second of life, forgetting about the needs of the dying person who has the personal dignity and the rights associated with it. The goal of treatment is more and more often not a human being as an integral whole, but a disease entity that is a source of income for a hospital ward. Despite such great advancement in technology and civilization, intensive care has encountered an insurmountable limit, namely that death is an inevitable fact in the life of every human being. Attempting to escape from it at all costs denies the basic tasks of medicine resulting from the Hippocratic tradition.

Among the medical staff of intensive care units, nurses constitute the immediate surroundings of a dying patient. They accompany the patient in the last moments of life, caring for the basic needs of the dying. Niedojad et al. [9] conducted research aimed at getting to know the opinion of nursing staff about death and dying and determining the impact of factors shaping the level of opinions presented in this regard. The research was carried out by means 
of a diagnostic survey in a group of 100 nurses. According to $20 \%$ of those surveyed, death is a defeat for the modern achievements of medicine, while the remaining part opposes this view. According to 97\% of respondents, the most ethical treatment in relation to a dying patient who is in a palliative state is to provide him/her with decent conditions for dying, with only $3 \%$ of nurses thinking that he/her should avail of persistent therapy and emergency measures. In the hospital, $91 \%$ of respondents believe that the process of dying is being prolonged while $9 \%$ consider it prolonging life.

The problem of the right to die is a specific point of reference for medical interactions, especially in the context of its progress, thus care for an individual experiencing pain, suffering and experiencing a terminal state. The right to die is the specifics of palliative care, whose task is to achieve optimal quality of life for terminally ill people and their families, while paying attention to the natural character of the process of dying and death itself [10].

\section{CONCLUSION}

In conclusion, the identification of brain death with individual death not only removes from physicians the obligation to artificially support patients who could not be helped by medicine, but has also opened the way for the development of transplantology and help patients who have been condemned to death [11]. The death of the brain has always been controversial, since its social perception depends not only on the attitudes of life and moral individuals, but also on the social and cultural context. The task of doctors, paramedics, nurses and all those involved in health care is to make society aware of what death of the brain actually is, along with the fact that it can be a gift of new life at the same time.
Conflict of interest: The authors declare that they have no conflicts of interest. None of authors involved in this study have any financial relationship.

Source of support: No sources of financial and material support to be declared.

Name of the department and institution in which the work was carried out: Department of Nephrology Nursing, Medical University of Warsaw, Poland.

\section{REFERENCES}

1. Pabisiak K. Brain death criteria formulated for transplantation purposes: fact or myth? Anaesthesiol Intensive Ther. 2016; 48(2): 142-145, doi: 10.5603/AlT.a2016.0015, indexed in Pubmed: 26976095.

2. Gilder S. Twenty-second World Medical Assembly. BMJ. 1968; 3(5616): 493-494, doi: 10.1136/bmj.3.5616.493.

3. Iwańczuk W. Śmierć mózgu. Cornetis, Wrocław 2010: 16-49.

4. Wójcik B. Śmierć mózgu jako kryterium śmierci człowieka. Problematyka filozoficzno-etyczna. Medycyna praktyczna. http://www.mp.pl/ etyka/ kres_zycia/32159,smierc-mozgu-jako-kryterium-smierci-czlowieka-problematyka-filozoficzno-etyczna (21.05.2007).

5. Załącznik do obwieszczenia Ministra Zdrowia z dnia 17 lipca 2007 Kryteria i sposób stwierdzenia trwałego nieodwracalnego ustania czynności mózgu ustalone przez specjalistów z dziedzin medycyny: anestezjologii i intensywnej terapii, neurologii, neurochirurgii i medycyny sadowej.

6. Iwanczuk W. Spontaneous movements in a brain stem dead patient. Case report. Anest. Intens. TeR. 2005; 3: 193-196.

7. Kliś A, Trzcińska A. Opinia pielęgniarek i położnych na temat transplantacji narządów. Pielęg Chirurg Angiol. 2015; 3: 182-186.

8. https://www.pch24.pl/profesor-jan-talar--nie-stwierdzalem-nigdysmierci-mozgu---to-nielekarskie-i-nieetyczne,57506,i.html.

9. Niedojad K, Rybka M, Rezmerska L, et al. Death and dying in the opinion of nursing Staff. Pielęgniarstwo w Opiece Długoterminowej. 2016; 3: 12-18.

10. Sobczak K, Janaszczyk A, Leoniuk K. Prawo do śmierci - lekarz i chory w obliczu śmierci. Medycyna Paliatywna w Praktyce. 2012; 6(2): 39-45.

11. Sobczak K, Janaszczyk A. Kontrowersje wokół neurologicznego kryterium śmierci mózgu. Forum Medycyny Rodzinnej. 2012; 4: 182-190. 